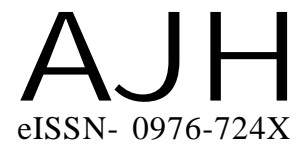

Received : 29.06.2016

Revised : 14.10 .2016

Accepted : 28.10.2016

Members of the Research Forum

Associated Authors:

${ }^{1}$ Krishi Vigyan Kendra (U.A.S.),

Konehalli, TUMKURU

(KARNATAKA) INDIA

Email : kvktumkur@gmail.com
Author for correspondence : NAGAPPA DESAI

Krishi Vigyan Kendra (U.A.S.),

Konehalli, TUMKURU

(KARNATAKA) INDIA

Email : agridesai@gmail.com
THEASIAN JOURNAL OF HORTICULTURE

Volume 11 | Issue 2 | December, 2016 | 301-305

Visit us -www.researchjournal.co.in

RESEARCH PAPER

DOI : 10.15740/HAS/TAJH/11.2/301-305

\title{
Problems experienced by farmers in arecanut cultivation
}

\section{NAGAPPA DESAI, T.S. SUKANYA ${ }^{1}$ AND B. MAMATHA ${ }^{1}$}

ABSTRACT : The studies were conducted on problems experienced by farmers in arecanut cultivation. Observation was found that 16 per cent of yield gap between demonstration plot and actual farmers plot yield in arecanut. The total yield gap between potential yield and actual yield was 32 per cent. Majority of the big farmers (66\%) and small farmers (50\%) were medium level of adoption. Majority of the big farmers fully adopted the practices like spacing, pit size, number of seedlings per acre and drip irrigation methods, whereas technologies fully adopted by small farmers were pit size (86\%), number of seedlings per acre (74\%) and spacing (66\%). Cent per cent of small and big farmers have not applied weedicide. More than 70 per cent of small farmers have not adopted technologies such as improved variety selection, good quality seedling selection procedure, recommended dose of inorganic fertilizers and red palm weevil management, more than half of the big farmers did not adopt seedling selection procedure, pulse crops as intercrops and red palm weevil management practices. High cost and non availability of labour, erratic supply of electricity and low price for the produce were the major production constraints perceived by the arecanut growers. A great majority of big and small farmers opined that providing continuous power supply, fixed price for the produce, create awareness programmes for control of pest and diseases were the major suggestions to overcome the production constraint of arecanut by the farmers.

KEY WORDS : Adoption, Arecanut, Constraint, Demo, Extension, Yield

HOW TO CITE THIS ARTICLE : Desai, Nagappa, Sukanya, T.S. and Mamatha, B. (2016). Problems experienced by farmers in arecanut cultivation. Asian J. Hort., 11(2) : 301-305, DOI : 10.15740/HAS/ TAJH/11.2/301-305. 